\title{
KARAKTER ANAK \\ DALAM NOVEL NEGERI LIMA MENARA: PERSPEKTIF NILAI AJARAN ISLAM
}

\author{
Novi Maria Ulfah ${ }^{1}$ \\ IAIN Walisongo Semarang \\ email: unonovi@gmail.com
}

\begin{abstract}
Abstrak
Tulisan ini bermaksud mencari nilai-nilai karakter apa saja yang terkandung dalam novel Negeri Lima Menara. Novel Negeri Lima Menara merupakan novel yang terinspirasi dari kisah nyata dari sang penulis yaitu Ahmad Fuadi. Novel ini bercerita mengenai keseharian Ahmad Fuadi ketika menuntut ilmu di pondok modern gontor. Nilai-nilai karakter yang peneliti temukan kemudian dianalisis menggunakan kajian intertekstual. Kajian intertekstual dimaksudkan untuk menghubungkan nilai-nilai karakter tersebut dengan ayat al-Qur'an dan Hadits. Nilai-nilai karakter dalam novel Negeri Lima Menara antara lain: keikhlasan, patuh, giat belajar, kebersamaan, jujur, gigih, tawakkal, ikhtiar, optimis, sungguh-sungguh, setia kawan, qanaah, minta ampun, berani, persatuan serta pengorbanan. Nilai pendidikan tersebut mempunyai korelasi dengan beberapa ayat al-Qur'an dan al Hadits. Dalam kajian intertekstual, ayat al-Qur'an dan hadits merupakan hipogram atas nilai-nilai karakter tersebut.
\end{abstract}

Kata Kunci: novel Negeri Lima Menara, pendidikan karakter anak

\section{A. Pendahuluan}

Karya sastra sebagaimana dikatakan Teeuw, adalah jalan kebenaran keempat, di samping jalan falsafat, agama, dan ilmu pengetahuan. Falsafat dan ilmu pengetahuan adalah gejala baru dalam sejarah kebudayaan,

\footnotetext{
${ }^{1}$ Penulis adalah dosen Fakultas Dakwah dan Komunikasi, pemerhati sastra anak di Kota Semarang.
} 
meskipun dalam masyarakat tradisional sudah dapat kita temui berbagai macam hal dan gejala yang mengikuti kajian di bidang falsafat atau ilmu pengetahuan modern. Melalui tokoh-tokoh dalam karya sastra berupa syair, novel atau hikayat, sastrawan yang beriman dapat menampilkan misalnya, bagaimana watak seorang pemimpin Islam yang berjuang membela rakyat miskin, melawan penindasan, menegakkan demokrasi, mewujudkan kemakmuran yang merata dan membangun lembaga pendidikan untuk mencerdaskan bangsa. Melalui karya sastra, pengarangnya dapat mengarah kepada pentingnya membangun masyarakat yang hidup rukun, damai, tolong menolong, yang pandai mengajari yang bodoh, yang memerintah mengasihi yang diperintah, dan sebagainya. ${ }^{2}$

Melalui novel, kita dapat menuangkan pesan-pesan moral atau kandungan isi al-Qur'an dan al-Hadits. Bahasa novel dikemas dengan bahasa ringan sehingga mudah dipahami para pembacanya. Selain itu, pembaca tidak harus merasa digurui atau pun diceramahi.

Bentuk sastra islami merupakan hasil perpaduan antara budaya dan nilai-nilai ajaran agama yang telah dihayati oleh pengarangnya. Dalam karya sastra seperti itu, tergambarkan adanya reaksi aktif pengarang dalam menghayati makna kehadiran keagamaan yang dipeluknya secara teguh. Sastra tumbuh dari sesuatu yang bersifat religious. Jika dilacak jauh ke belakang, kehadiran unsur keagamaan dalam sastra setua keberadaan sastra itu sendiri.

Batasan-batasan tentang karya sastra Islam banyak disampaikan oleh para pakar sastra. Mereka menyampaikan batasan-batasan tentang pengertian sastra islam, di dalamnya termasuk novel islami. Untuk mengenali sastra islam, baik puisi, cerpen, maupun novel, tidak akan melalaikan pembacanya dari mengingatkan kebesaran Allah dan rasul-Nya. Selain itu, mengingatkan pembaca tentang pentingnya cinta pada kaum muslimin dan semua makhluk Allah: semua manusia, hewan, tumbuhan, alam raya dan sebagainya. Ciri lainnya, novel islami tidak mendeskripsikan hubungan

${ }^{2}$ Nabilah Lubis, Penelitian Teks dan Metode Penelitian Filologi, (Jakarta: Yayasan Media Alo Indonesia, 2001), hlm. 13. 
badani, kemolekan tubuh perempuan atau betapa "indahnya" kemaksiatan, secara vulgar dengan mengatasnamakan seni atau aliran sastra apa pun.

Asep Supriadi menulis bahwa, novel islami mempunyai ciri antara lain: 1) Novel yang menampilkan cerita tentang kehidupan manusia yang mengingatkan kita sebagai hamba Allah; 2) Novel yang ceritanya sesuai dengan pandangan Islam; 3) Novel yang menonjolkan nilai-nilai baik dan mulia, aspek-aspek kemungkaran hanya digambarkan sebagai pembanding dan akhirnya kemungkaran itu dapat dikalahkan oleh kebaikan; 4) Novel yang ceritanya menyampaikan kebenaran sesuai dengan pandangan Islam; 5) Novel yang mengandung unsur estetika seni; dan 6) Novel yang menggunakan gaya bahasa yang indah. ${ }^{3}$

Dari pengertian-pengertian di atas nampak, sedikitnya ada tiga syarat umum sebuah karya sastra dikatakan sastra islam (dalam hal ini novel islami) yaitu: 1) Penulisnya adalah seorang muslim yang sadar dan bertanggung jawab akan kesucian agama; 2) Karya kreatif yang dihasilkan sejalan dengan nilai-nilai ajaran islam dan tidak bertentangan dengan syariat islam; serta 3) Karya yang mempunyai daya tarik universal dan dapat bermanfaat bagi masyarakat mana pun karena islam adalah agama fitrah. Pengertianpengertian tentang sastra islam di atas menyatakan bahwa sastra islam (termasuk novel islami) adalah karya sastra yang di dalamnya terkandung nilai-nilai ajaran islam, yang bermuara kepada ketauhidan yang bersumber dari al-Qur'an dan al Hadis Nabi, serta bertujuan sebagai sarana dakwah.

Novel Negeri Lima Menara merupakan sebuah novel yang terinspirasi dari kisah nyata ketika penulis berada di Pondok Modern Gontor Ponorogo. Pada awalnya penulis yaitu Ahmad Fuadi setelah menyelesaikan sekolah Madrasah Tsanawiyah berniat melanjutkan pendidikan ke sekolah umum (SMA). Pikirnya, akan mudah masuk perguruan tinggi ITB (Institut Teknologi Bandung) kalau melanjutkan sekolah di SMU. Tetapi sang ibu tidak mengijinkan penulis untuk sekolah di SMU, dan menginginkan anaknya masuk ke sekolah agama agar menjadi seorang ulama.

\footnotetext{
${ }^{3}$ Asep Supriyadi, “Transformasi Nilai-nilai Ajaran Islam dalam Ayat-Ayat Cinta Karya Habiburrahman El Shirazy: Kajian Interteks", (Semarang: Program Pascasarjana UNDIP, 2006), hlm. 20.
} 
Meskipun dengan disertai protes selama tiga hari dengan mogok bicara, pada akhirnya sang penulis memutuskan sendiri untuk melanjutkan sekolah agama dan tinggal di Pondok Modern Gontor Ponorogo Jawa Timur. Dengan ditemani sang ayah berangkatlah tokoh Alif Fikri (Ahmad Fuadi) dari Sumatera Barat ke Jawa Timur selama tiga hari. Novel ini berkisah tentang keseharian tokoh Alif Fikri selama di Pondok Modern Gontor, sehingga syarat dengan transformasi nilai-nilai ajaran Islam.

Tokoh yang terdapat dalam novel ini antara lain: Alif Fikri (terinspirasi dari tokoh Ahmad Fuadi) yang berasal dari Sumatera Barat, Raja (terinspirasi dari tokoh Adnin Armas) yang berasal dari Medan (Sumatera Utara), Baso Sholahuddin (terinspirasi dari tokoh Ikhlas Budiman) yang berasal dari Sulawesi, Atang (terinspirasi dari tokoh Kuswandani) dari Bandung Jawa Barat, Dulmadjid (Muhammad Monib) berasal dari Madura, serta Said yang berasal dari Surabaya Jawa Timur. Mereka berenam terbiasa menghabiskan waktu sore dengan duduk bercerita di bawah menara masjid, sehingga mereka berenam mempunyai julukan sahibul menara.

Penelitian ini juga menggunakan kajian intertekstual sebagai bahan analisis terhadap nilai-nilai karakter yang ditemukan dalam novel Negeri Lima Menara. Istilah intertekstualitas (intertuality ing; intertextualite-prc) pada mulanya dikenalkan oleh Julia Kristeva. ${ }^{4}$ Intertekstualitas secara mudahnya dapat didefinisikan sebagai relasi di antara teks dengan teks-teks lain. Dengan demikian, dipandang dari sudut pandang pembaca, sebuah teks hanya bisa dipahami dalam hubungannya atau pertentangannya dengan teks-teks lain. $^{5}$

\footnotetext{
${ }^{4}$ Julia kristeva lahir di Bulgaria pada tahun 1941. Ia adalah seorang linguis dan ahli semiotic ketika ia bergabung dengan kelompok Tel Quel di Paris pada akhir tahun 19601970an, karya Kristeva banyak berbicara tentang bahasa, subyektifitas, dan seksualtas (dilandasi psikoanalisis Lacanian. Ia juga seorang feminis kontemporer , professor di bidang linguistik pada Universitas Paris VIII, dan juga seorang psikoanalisis. Melalui semiotika revolusionernya, ia mengembangkan kemungkinan bentuk pelanggaran, subversi dan kreativitas antisosial dalam bahasa. Sebagaimana halnya Derrida, Kristeva menjadikan semiotika struktural Saussure sebagai obyek subversi dan pembongkaran. Kristeva melihat semiotika Saussurean sebagai satu wacana yang hanya menawarkan makna tunggal, disebabkan di dalam menjelajahi ruang epistemologinya, menolak hadirnya subyek sebagai agen perubahan dan subversi bahasa.

${ }^{5}$ Jonathan Culler, Structuralist Poetics: Structuralism, Linguistic, and the Study of Literature, (New York: Cornell University Press, 1982), hlm. 139.
} 
Kristeva ${ }^{6}$ mencoba membatasi intertekstualitas dalam beberapa rumusan. Pertama, intertektualitas ${ }^{7}$ adalah transposisi dari satu atau beberapa sistem tanda kepada sistem tanda yang lain dengan disertai oleh sebuah artikulasi baru. Kedua, sebuah teks adalah produktivitas, ia merupakan permutasi dari teks-teks lain: di dalam ruang sebuah teks terdapat ujaran-ujaran (utterance) yang berasal dari teks-teks lain yang saling bersilangan dan saling menetralkan. Ketiga, Kristeva juga mengatakan bahwa "setiap teks mengambil wujud sebagai suatu mozaik kutipan-kutipan, setiap teks merupakan resapan dan transformasi dari teks-teks lain". ${ }^{8}$ Pengertian yang terakhir ini mengingatkan kembali Mikhail Bakhtin yang pernah menyatakan bahwa teks sastra merupakan sebuah mozaik kutipan yang berlapis-lapis (multi-layered) yang membentuk sebuah struktur yang dialogis dan polifonik.

Hal yang sama pun diungkap oleh Rifattere. ${ }^{9}$ Ia mengembangkan pemikiran tentang fenomena intertekstualitas dengan mengusulkan istilah atau konsep lain yang berkaitan, bahkan tumpang tindih dengannya, yaitu derivasi hipogramatik (hypogramatik derivation). Riffaterre berpijak pada asumsi bahwa pembaca tidak mungkin memahami semiosis apabila dia tidak

${ }^{6}$ Salah satu konsep Kristeva adalah semanalysis yaitu metode yang memusatkan perhatian bukan semata-mata fungsi bahasa sebagai sarana komunikasi, melainkan juga pada material bahasa, seperti: suara, irama, dan ciri-ciri grafis. Kristeva merupakan seorang ahli bahasa yang kemudian terjun ke dalam dunia kritik feminis.

${ }^{7}$ Prinsip yang paling mendasar dari intertekstualitas adalah bahwa seperti halnya tandatanda yang mengacu kepada tanda-tanda yang lain, setiap teks mengacu kepada teks yang lain. Dengan kata lain, intertekstualitas dapat dirumuskan secara sederhana sebagai hubungan antara sebuah teks tertentu dengan teks-teks lain. Gerakan intertekstualitas ini tanpa batas, sejajar dengan proses semiosis yang juga tidak berujung pangkal sebagaimana dikatakan Kristeva," setiap teks memperoleh bentuknya sebagai mozaik kutipan-kutipan, setiap teks merupakan rembesan dan transformasi dari teks-teks lain." Sebuah karya hanya dapat dibaca dalam kaitannya dengan atau dalam pertentangannya terhadap teks-teks yang lain yang menjadi resapannya. Melalui hal terakhir inilah seseorang, beserta harapan-harapannya, dapat membaca dan menstruktur teks, menemukan cri-ciri yang menonjol di dalam sebuah teks dan memberikannya sebuah struktur.

${ }^{8}$ Kris Budiman, Semiotika Visual (Konsep, Isu dan Problem Ikonitas), (Yogyakarta: Jalasutra, 2011), hlm. 53.

${ }^{9}$ Nama lengkapnya adalah Michael Riffaterre yang lahir pada tanggal 20 November 1924, meninggal pada tahun 27 Mei 2006. Ia orang Perancis strukturalis teori sastra dan seorang professor di Columbia University. Dia menulis karyanya dalam bahasa Perancis dan Inggris. Ia dikenal strukturalis semiotika. 
menentukan lebih dahulu letak teks yang dihadapinya sebagai sebuah tanda yang berada di dalam suatu sistem atau jaringan (network). Dengan kata lain, makna sebuah teks sangat tergantung kepada hubungan intertekstualitasnya, tergantung sepenuhnya kepada kemampuan pembaca untuk mengenali kaitan dan konflik di antara teks tersebut dengan teks-teks lain. ${ }^{10}$

Lebih lanjut Riffaterre dikutip oleh Kris Budiman melihat bahwa produksi tanda-tanda puitik pun ditentukan oleh derivasi hipogramatik ini: suatu tanda atau serangkaian tanda akan menjadi puitik apabila mengacu kepada atau memolakan diri terhadap sekelompok tanda yang telah ada sebelumnya. Sebuah hipogram (hypogram) yang sebelumnya disebut sebagai "teks latar" atau "teks acuan", merupakan sebuah teks atau setidaknya suatu sistem tanda-tanda yang terdiri atas sebuah predikasi. Hipogram bersifat potensial (dapat teramati di dalam bahasa) atau aktual (dapat diamati di dalam teks yang telah ada sebelumnya).

Hipogram potensial adalah segala bentuk implikasi dari makna kebahasaan, yaitu yang berupa presuposisi dan makna konotatif yang sudah dianggap umum. Implikasi ini tidak dapat ditemukan dalam kamus, baik kamus ekabahasa maupun kamus dwibahasa, karena implikasi bukan berdasarkan pada arti denotatif kebahasaan. Implikasi itu sebenarnya telah ada pada pikiran penutur bahasa pada umumnya. ${ }^{11}$

Hipogram aktual adalah teks nyata, yang dapat berupa kata, frase, kalimat, peribahasa, atau seluruh teks, yang menjadi latar penciptaan teks baru sehingga signifikasi teks harus ditemukan dengan mengacu pada teks lain atau teks yang sudah ada sebelumnya. Teks dalam pengertian umum bukan hanya teks tertulis atau teks lisan, tetapi juga adat-istiadat, kebudayaan, agama dan bahkan seluruh isi alam semesta (dunia) ini adalah teks. ${ }^{12}$

Oleh sebab itu, hipogram yang menjadi latar penciptaan teks baru itu, bukan hanya teks tertulis atau teks lisan, tetapi juga dapat berupa adat-

\footnotetext{
${ }^{10}$ Rifattere, Semiotic of Poetry, (London: Indiana University Press, 1978), hlm. 110. hlm. 234.

${ }^{11}$ Puji Santosa, Rancangan Semiotika dan Pengkajian Susastra, (Bandung: Angkasa, 2004),

12 Rachmat Djoko Pradopo, Kritik Sastra Indonesia Modern, (Yogyakarta: Gama Media, 2002), hlm. 132.
} 
istiadat, kebudayaan, agama, bahkan dunia ini. Hipogram tersebut direspons atau ditanggapi oleh teks baru. Novel Negeri Lima Menara lahir karena adanya persepsi pengarang terhadap teks-teks lain, yaitu teks alQur'an dan Hadis Nabi. Dengan demikian, novel Negeri Lima Menara merupakan teks transformasi, sedangkan teks al-Qur'an dan Hadis Nabi merupakan teks hipogram.

\section{B. Pendidikan Karakter}

Secara etimologis, kata karakter (Inggris: character) berasal dari bahasa Yunani (greek), yaitu charrasein yang berarti "to engrave". Dalam Kamus Bahasa Indonesia kata "karakter" diartikan sebagai tabiat, sifat-sifat, kejiwaan, akhlak, atau budi pekerti yang membedakan seseorang dengan yang lain, dan watak. Karakter juga bisa berarti huruf, angka, ruang, simbol khusus yang dapat dimunculkan pada layar dengan papan ketik. Orang berkarakter berarti orang yang berkepribadian, berperilaku, bersifat, bertabiat, atau berwatak. Dengan makna seperti ini, karakter identik dengan kepribadian dan akhlak. Kepribadian merupakan ciri atau karakteristik, sifat khas diri seseorang yang bersumber dari bentukan-bentukan yang diterima dari lingkungan, misalnya keluarga pada masa kecil. ${ }^{13}$

Secara etimologis, makna karakter dikemukakan oleh Thomas Lickona. Menurutnya, karakter adalah: " a reliable inner diposition to respon the situations in a morally good way". Menurut Lickona karakter mulia (good character) meliputi pengetahuan tentang kebaikan, lalu menimbulkan komitmen (niat) terhadap kebaikan, dan akhirnya benar-benar melakukan kebaikan. Dengan kata lain, karakter mengacu kepada serangkaian pemikiran (cognitive), perasaan (affectives), dan perilaku (behavior) yang sudah menjadi kebiasaan (habbits). ${ }^{14}$

Terminology pendidikan karakter mulai dikenalkan sejak tahun 1900an. Thomas Lickona dianggap sebagai pengusungnya, terutama ketika ia

\footnotetext{
${ }_{13}$ Sutrisno dan Subiyantoro, Kontribusi Madrasah dalam Pembentukan Karakter Bangsa,. (Yogyakarta: UIN Yogyakarta, 2013), hlm. 6.

${ }^{14}$ Darmiyati Zuchdi, Pendidikan Karakter, Konsep Dasar dan Implementasi di Perguruan Tinggi, (Yogyakarta: UNY Press, 2012), hlm. 15.
} 
menulis buku yang berjudul The Return of Character Education dan kemudian disusul dengan bukunya Education For Character. How Our School Can Teach Respect and Responsibility. Melalui buku tersebut, ia menyadarkan dunia barat akan pentingnya pendidikan karakter. Pendidikan karakter menurut lickona mengandung tiga unsur pokok, yaitu mengetahui kebaikan (knowing the good), mencintai kebaikan (desiring the good) dan melakukan kebaikan ( doing the good). Pendidikan karakter tidak sekadar mengajarkan mana yang benar dan mana yang salah kepada anak, tetapi lebih dari itu, pendidikan karakter menanamkan kebiasaan (habituation) tentang yang baik, sehingga peserta didik paham, mampu merasakan, dan mau melakukan yang baik. Pendidikan karakter ini membawa misi yang sama dengan pendidikan moral atau akhlak.

Pendidikan karakter adalah usaha sengaja dan sadar untuk mewujudkan kebajikan, yaitu kualitas kemanusiaan yang baik secara objektif, bukan hanya baik untuk individu perseorangan, tetapi juga baik untuk masyarakat secara keseluruhan. Menurut David Elkind dan Freeddy Sweet, character education is the deliberate effort to help people understand, care about, and act upon core ethical value (pendidikan karakter adalah usaha sengaja untuk membantu manusia memahami, peduli tentang, dan melaksanakan nilainilai etika inti). ${ }^{15}$

Howard kirschenbaun menguraikan 100 cara untuk bisa meningkatkan nilai dan moralitas (karakter/akhlak mulia) di sekolah yang bisa dikelompokkan ke dalam lima metode: 1) inculcating values and morality (penanaman nilainilai dan moralitas); 2) modeling values and morality) pemodelan nilai-nilai dan moralitas; 3) facilitating values and morality (memfasilitasi nilai-nilai dan moralitas; 4) skill for value development and moral literacy (keterampilan untuk mengembangkan nilai dan literasi moral); 5) developing values education program (mengembangkan program pendidikan nilai).

Dari uraian di atas jelaslah bahwa membangun kultur atau lingkungan yang mendukung terwujudnya tujuan pendidikan yaitu karakter mulia,

\footnotetext{
${ }^{15}$ Zubaidi, Desain Pendidikan Karakter Konsepsi dan Aplikasi dalam Lembaga Pendidikan, (Jakarta: Kencana, 2012), hlm. 14.
} 
sangatlah penting. Tiga lingkungan utama peserta didik, yaitu lingkungan sekolah/madrasah, lingkungan keluarga, dan lingkungan masyarakat hendaklah dibangun sinergis dan bersama-sama mendukung proses pendidikan dan pembelajaran di kelas. Lingkungan yang jelek tidak hanya menghalangi tercapainya tujuan pendidikan, akan tetapi juga akan merusak karakter peserta didik yang dibangun melalui proses pembelajaran di kelas. ${ }^{16}$

Novel Negeri Lima Menara yang menceritakan kisah keseharian selama di pesantren merupakan penggambaran pendidikan karakter. Pesantren atau madrasah merupakan sekolah umum yang berciri khas keislaman. Keyakinan dan nilai yang dikembangkan di madrasah berorientasi kepada nilai religiusitas yang bersumber dari al-Qur'an dan al-Sunnah yaitu: 1) berorientasi kepada Tuhan pencipta; 2) berorientasi kearah hubungan dengan sesama manusia; 3) berorientasi ke arah pola hubungan manusia dengan alam. ${ }^{17}$

Konsep diri siswa siswa madrasah dibangun melalui interaksinya dengan warga madrasah yang lain, yang banyak dikemas melalui berbagai aktivitas keagamaan di madrasah. Aktivitas tersebut dapat berupa kegiatan teoritis dan praktis, sehingga memungkinkankan terciptanya siswa yang beragama secara kaffah. Agama yang dipegang sebagai sistem kehidupan, bukan hanya dipahami sebagai ritual saja, tetapi agama yang menyatu secara utuh. Kegiatan riil di madarasah seperti shlat berjamaah, kegiatan shalat Dhuha, tadarus rutin pagi sebelum pembelajaran. Di samping itu, ada pembinaan-pembinaan khusus seperti bimbingan baca al-Qur'an dan kajian Jumat. Ada beberapa madrasah yang sudah memprogramkan kegiatan qiyamul lail.

Aktifitas kultur keagamaan tersebut sudah berjalan sejak berdirinya madrasah, dan didukung dengan pengkondisian fisik karena keyakinan di madrasah, tentang kualitas daya dukung tentunya berkaitan dengan kekuatan daya finansial masing-masing madrasah. Tetapi semangat anggota madrasah itulah yang menjadi kekuatan untuk mewujudkan out put peserta didik yang berkarakter religious. Hal ini telah menjadi bukti nyata bahwa

${ }^{16}$ Darmiyati Zuchdi, Pendidikan Karakter..., hlm. 25.

${ }^{17}$ Arifin Muzayyin, Kapita Selekta Pendidikan Islam, (Jakarta: Bumi Aksara, 2003), hlm. 49. 
madrasah telah memberikan kontribusi secara signifikan dalam membentuk karakter bangsa yang religious.

Karakter merupakan nilai-nilai yang khas baik (tahu nilai kebaikan, mau berbuat baik, nyata berkehidupan baik, dan berdampak baik terhadap lingkungan) yang terpatri dalam diri dan terejawantahkan dalam perilaku. Karakter secara koheren memancar dari hasil olah pikir, olah hati, olah raga, serta olah rasa dan karsa seseorang atau sekelompok orang. Karakter merupakan ciri khas seseorang atau sekelompok orang yang mengandung nilai, kemampuan, kapasitas moral, dan ketegaran dalam menghadapi kesulitan dan tantangan. ${ }^{18}$

Lebih lanjut, menurut Soegito karakter individu terbagi menjadi: 1) karakter yang bersumber dari olah hati yang meliputi: beriman, bertakwa, jujur, amanah, adil, tertib, taat peraturan, bertanggungjawab, berempati, berani mengambil resiko, pantang menyerah, rela berkorban dan berjiwa patriotik; 2) karakter yang bersumber dari olah pikir yaitu: cerdas, kritis, inovatif, ingin tahu, produktif, berorientasi iptek, dan reflektif; 3) karakter yang bersumber dari olah raga/kinestetika yaitu: bersih, sehat, sportif, tangguh, andal, berdaya tahan, bersahabat, kooperatif, kompetitif, ceria dan gigih; 4) karakter yang bersumber dari olah rasa dan karsa antara lain: kemanusiaan, saling menghargai, gotong royong, kebersamaan, ramah, hormat, toleran, nasionalis, peduli, mengutamakan kepentingan umum, dinamis, kerja keras, dan beretos kerja.

\section{Pendidikan Karakter Anak dalam Novel Negeri Lima Menara}

Nilai pendidikan karakter anak dalam novel Negeri Lima Menara antara lain:

\section{Keikhlasan}

Keikhlasan merupakan nilai pendidikan anak sering muncul dalam novel Negeri Lima Menara. Hal ini dapat dilihat dari: pertama, keikhlasan

18 AT. Soegito, Kontribusi PAI terhadap Pembentukan Karakter Bangsa, (Semarang: Universitas Negeri Semarang, 2013), hlm. 1. 
Amak menjadi guru honorer madrasah selama tujuh tahun hanya digaji dengan beras. Kedua, para ustadz di Pondok Madani pun mengajar tanpa diberi gaji uang. Mereka tinggal dan diberi fasilitas yang cukup dari pondok. Ketiga, segala kegiatan yang berlangsung selama di pondok pun harus dilandasi dengan keikhlasan. Para murid ketika mendapat hukuman dari pengurus juga harus mengikhlaskannya. Nilai keikhlasan merupakan teks transformasi dari ayat al-Qur'an surat al-Baqarah ayat 286. Sedangkan haditsnya diambil dari kitab mukhtarah min shahihain juz I halaman 2. Inti dari hadits tersebut yaitu: segala sesuatu tergantung dari niatnya dan semuanya akan mendapatkan balasan dari apa yang sudah diniatkan. Ayat al-Qur'an dan hadits ini merupakan hipogram dari nilai keikhlasan.

\section{Patuh}

Tujuan Amak mengirim Alif untuk belajar agama adalah untuk menjadi pemimpin agama atau ulama. Amak prihatin dengan kondisi pemimpin agama yang kurang cakap. Menurut Amak, banyak anak yang dimasukkan ke dalam pesantren berasal dari anak yang kurang pandai. Sehingga menghasilkan pemimpin agama yang kurang cakap pula. Amak pun menginginkan Alif menjadi seperti buya HAMKA. Di Pondok Madani juga secara tidak langsung para santri sudah mempraktikkan menjadi seorang pemimpin. Hal ini ditunjukkan dengan menjadi imam shalat, ketua asrama, ketua regu dan ketua kamar. Hipogram dari teks untuk patuh terhadap pemimpin adalah QS. al-Nisa ayat 59, yang intinya "agar orang beriman untuk taat kepada Allah dan rasul-Nya serta kepada ulil amri/pemimpin". Sedangkan Hadits Nabi berasal dari kitab Akhbar al-Ashhab juz 9 yang artinya: bagi para pemimpin akan dimintai pertanggungjawaban atas kepemimpinannya.

Selain patuh terhadap pemimpin terdapat juga nilai patuh terhadap orang tua. Meskipun Alif berkeras hati tidak mau melanjutkan ke pondok pada akhirnya ia pun bersedia untuk belajar di sana. Ia patuh terhadap perintah ibunya untuk belajar agama. Kiai Rais (kiai di Pondok Madani) mengajarkan para santrinya untuk birrul walidain. Berbakti kepada kedua orang tua, tidak boleh berkata kasar, patuh terhadap perintah keduanya selama tidak menyuruh kepada kekafiran. QS al-Isra' ayat 23 dan 24 merupakan hipogram dari teks transformasi birrul walidain. Inti dari ayat ini: 
"Hendaknya untuk berbuat baik kepada ibu bapakmu dengan sebaikbaiknya. Jika sudah berusia lanjut, untuk tidak berkata kasar apalagi membentaknya. Mendoakannya, agar Allah mengasihi sebagiamana kedua orang tua mengasihi kita sewaktu kecil."

Sedangkan haditsnya, diriwayatkan oleh Abu Hurairah ra, datanglah seorang lelaki yang menanyakan kepada rasul kepada siapa ia harus berlaku baik. Rasul pun menjawab, yaitu kepada ibu, ibu dan ibu. Diulangilah sampai tiga kali baru kemudian bapakmu.

Terdapat juga nilai kepatuhan terhadap hukum atau aturan selama menjadi santri di pondok madani. Patuh terhadap aturan merupakan hal yang penting ketika belajar di Pondok Madani. Jika tidak, sama saja dengan menjadikan diri sebagai umpan para jasus (mata-mata), kemudian menjadi jasus itu sendiri. Para jasus yang menyamar sangat efektif untuk menekan kesalahan yang terjadi di Pondok Madani. Aturan di pondok yang rawan pelanggaran antara lain, memotong antrian secara diam-diam di kamar mandi umum, makan serta minum di lapangan. Aturan di pondok kalau makan dan minum harus sambil duduk. Patuh terhadap hukum sama artinya dengan patuh terhadap syar'i dalam agama islam. Hal ini dapat dilihat dalam QS. al-Nisa ayat 59 yang intinya: "Agar taat kepada Allah, Rasul dan ulil amri. Jika terdapat perselisihan hendaklah kembali kepada al-Qur'an dan Hadits".

Patuh terhadap peraturan juga terlihat dari sikap Alif yang tidak mau menjalin hubungan dengan lain jenis. Bagi seorang muslim, secara hukum, sebenarnya tidak diperbolehkan saling bertatap muka dengan lain jenis. Ketika bertemu pun dianjurkan untuk menundukkan pandangan. Di Pondok Madani, berhubungan akrab dengan lain jenis atau berpacaran merupakan hal yang dilarang. Jangankan saling bertemu, berkirim surat pun dilarang. Hukumannya yang paling ringan di cukur botak dan yang paling berat dikeluarkan dari Pondok Madani. Hal ini sudah diatur dalam surah alNur ayat 30-31 yaitu:

"Bagi kaum laki-laki yang beriman hendaknya menahan pandangan dan memelihara kemaluannya. Juga kepada para perempuan agar menjaga pandangannya dan kemaluannya dan jangan menampakkan perhiasannya kecuali yang nampak dari padanya, dan juga menutup kain kudungnya sampai ke dadanya". 


\section{Giat Belajar}

Menuntut ilmu adalah kewajiban bagi muslim dan muslimat. Sejak dari ayunan sampai liang lahat, demikian kata pepatah. Kiai Rais pun berkata: "beruntunglah bagi para pencari ilmu. Allah akan memudahkan jalan ke surga. Para malaikat pun membentangkan sayap untuk para pencari ilmu, bahkan penghuni langit dan bumi sampai ikan paus memintakan ampun bagi orang yang berilmu". Sistem pendidikan di Pondok Madani pun tidak mengenal waktu. Dengan belajar 24 jam, diharapkan dapat menghasilkan manusia yang mandiri dan tangguh. Pendidikan pada dasarnya sama saja. Tidak ada dikotomi antara pendidikan umum dan pendidikan agama. Pendidikan model seperti ini yang diterapkan di Pondok Madani.

Keutamaan menuntut ilmu terdapat dalam QS. al-Taubah ayat 122.

"Dianjurkan bagi manusia tidak semua untuk pergi ke medan perang, tetapi ada sebagian yang memperdalam pengetahuan agama agar memberi peringatan kepada kaumnya".

Hadits Rasul yang diriwayatkan oleh Ibnu Abdul Barr bahwa:

"Rasul menganjurkan untuk mencari ilmu walau ke negeri cina dan kewajiban mencari ilmu adalah wajib atas kaum muslim".

Sebelum melakukan pekerjaan atau belajar dianjurkan untuk berdoa. Nuansa berdoa ketika mau belajar sangat kental dalam Pondok Madani. Kiai Rais selalu menganjurkan para santrinya agar berdoa sebelum belajar menjelang ujian atau dalam kesehariannya. Para ustad, terutama Kiai Rais pun mendoakan para muridnya agar diberi kemudahan dalam mencari ilmu. Berdoa merupakan teks tranformasi dari QS. al-Mu'min ayat 60. Allah berfirman agar manusia senantiasa berdoa maka akan dikabulkan. Orang yang tidak mau berdoa adalah orang sombong dan Allah tidak menyukai orang yang sombong.

\section{Kebersamaan}

Kebersamaan ditandai dengan dilakukannya shalat berjamaah setiap waktu. Shalat berjamaah sudah menjadi kebiasaan di Pondok Madani. Jika waktu magrib maka para santri melakukan shalat jamaah di masjid, selain 
waktu magrib, para santri melakukan shalat jamaah di dalam asrama. Setiap anak mendapat giliran menjadi imam shalat ketika melakukan shalat berjamaah di asrama. Allah sangat menganjurkan untuk melakukan shalat. Hal ini terdapat dalam surah Al Baqarah yang berbunyi anjuran untuk mendirikan (melakukan) shalat. Sedangkan hadits Nabi yang menjadi hipogram dari shalat jamaah diriwayatkan oleh Abdullah bin Umar. Abdullah berkata bahwa Rasul bersabda shalat berjamaah lebih utama dua puluh derajat dari shalat sendiri.

\section{Jujur}

Metode jasus (mata-mata) sangat efektif untuk menekan pelanggaran di Pondok Madani. Metode jasus yaitu seorang santri mendapat hukuman dari pengurus pondok dengan menjadi mata mata. Tugas jasus yaitu mencari tiga santri lainnya yang melakukan pelanggaran. Tugas menjadi jasus akan selesai jika ia sudah melakukan tugasnya dengan sempurna. Aturan di pondok banyak yang dilanggar oleh penghuni pondok. Selain itu, nilai kejujuran ditunjukkan saat ibu Alif pernah berbeda pendapat dengan teman gurunya di madrasah. Para guru sepakat untuk melonggarkan pengawasan ujian, bahkan mereka sepakat, memberikan jawaban atas pertanyaan yang sulit. Ibu Alif tetap pada pendiriannya, agar anak-anak mengerjakan ujian sesuai dengan kemampuannya, meskipun hasilnya jelek. Qulil haqqa walau kaana murran, katakanlah kebenaran walaupun pahit, merupakan hadis dan juga hipogram dari teks menjunjung tinggi nilai kebenaran.

\section{Gigih}

Ketika Alif mendapat hukuman menjadi jasus, Alif menemui kesulitan mencari temannya yang melakukan pelanggaran. Teman-temannya pun mencoba menawarkan bantuan, tetapi ia menolaknya.jika ia gagal, maka ia akan diganjar dua kartu lagi oleh pengurus pondok. Alif tetap tidak mau dibantu oleh temannya. Tidak gampang menyerah sesuai dengan ayat alQur'an yang melarang untuk putus asa terhadap rahmat Allah. Ayat ini tertuang dalan surah al-Zumar ayat 53-54. Selain anjuran untuk tidak putus asa terhadap rahmat Allah, juga untuk berserah diri kepada Allah. 


\section{Tawakkal}

Alif semakin panik ketika azan Ashar berkumandang kartu jasusnya masih kosong. Tawaran dari teman untuk menjadi asisten jasus pun ditolaknya. Bagi Alif kesalahan pribadi harus dibayar sendiri-sendiri. Ia pun teringat nasehat Kiai Rais: "Mandirilah maka kalian akan menjadi orang yang merdeka dan maju. Mandirilah kamu sekalian yang bergantung pada diri sendiri jangan bergantung kepada orang lain. Cukuplan bantuan Allah yang menjadi penolongmu."demikian tekad Alif. Ia tidak mau bergantung kepada belas kasihan orang lain. Teks ini merupakan transformasi dari alQur'an al-Nisa ayat 48. Disebutkan dalam ayat tersebut "bahwa Allah tidak akan mengampuni dosa syrik dan akan mengampuni dosa selain syrik bagi siapa yang dihendaki-Nya". Alif percaya atas bantuan dari Allah, dan dia tidak akan minta bantuan kepada selain Allah.

Sebuah keberhasilan merupakan kombinasi antara niat, usaha dan doa. Jika hanya mempunyai niat saja maka ia pun tidak akan berhasil. Demikian pula sebaliknya, jika hanya mempunyai usaha atau doa saja, maka belum bisa dikatakan berhasil." Pasang niat kuat, berusaha keras dan berdoa khusyu, lambat laun, apa yang kalian perjuangkan akan berhasil. Ini sunatullahhukum alam". Nasehat kiai Rais. Hadits Nabi mengenai pentingnya niat, usaha, dan doa dapat dijumpai dalam Syarah Tirmidzi juz 60 halaman 30 yang artinya Rasul bersabda "Allah tidak akan memandang rupa, warna kulit dan harta kita, akan tetapi Allah memandang kepada hati dan perbuatan kita".

Setelah semua niat, usaha dan doa telah dilakukan, maka tawakkal sebagai jalan terakhir. Berserah diri atas apa yang telah dilakukan. "Kerahkan semua kemampuan kalian dalam belajar! berikan yang terbaik! Baru setelah segala usaha disempurnakan berdoalah dan bertawakallah. Tugas kita hanya sampai usaha dan doa. Serahkan kepada Tuhan selebihnya, ikhlaskan keputusan kepada-Nya, sehingga kita tidak akan stress dalam hidup ini. Stress hanya bagi orang yang belum berusaha dan bertawakkal. Ma'an najah, good luck!" demikian pesan Ustad Salman. Konsep nilai tawakkal selaras dengan al-Qur'an surah Ali Imran ayat 159. Inti surat tersebut agar tawakkal kepada Allah. Tawakkal juga terdapat dalam surat al-Thalaq ayat 3 dan Ali Imran ayat 159. Hadits tentang tawakkal dikisahkan oleh sahabat Umar bin 
Khattab. Rasul bersabda: "jikalau kalian bertawakkal kepada Allah dengan sebenarnya, maka Allah akan memberikan rezeki seperti burung, pagi-pagi ia keluar dalam keadaan lapar dan pulang pada sore hari dalam keadaan kenyang."

Tidak jarang, Alif mengalami keterlambatan wesel (kiriman uang) dari orang tuanya. Pada suatu hari wesel yang ditunggu-tunggu tak kunjung datang. Ia mendapat surat dari Pak Etek Gindo (pamannya). Di dalam surat tersebut terdapat lipatan kertas karbon hitam yang di dalamnya terdapat dolar amerika sebanyak 20 dolar. Uang tersebut diberikan sebagai uang saku tambahan untuk Alif. Sikap percaya bahwa Allah akan memberikan rezeki dari jalan yang tidak terduga merupakan pentransformasian dari surah alThalaq ayat 3. Di dalam ayat tersebut dijelaskan mengenai rezeki yang datangnya dari Allah dan tidak disangka, juga anjuran untuk bertawakkal maka Allah akan mencukupkan apa yang menjadi keperluan manusia. QS. al-Baqarah ayat 172 juga membicarakan mengenai rezeki dari Allah.

\section{Ikhtiar}

Going to the extra mile, demikian nasehat Ustad Salman. Ia selalu memberi motivasi kepada para santri untuk selalu berusaha/ ikhtiar agar menjadi orang yang sukses. Going to the extra miles, tidak menyerah dengan rata-rata." Kalau orang belajar satu jam, maka ia akan belajar lima jam. Kalau orang berlari dua kilo maka ia akan berlari tiga kilo. Kalau orang menyerah pada detik 10, maka ia akan menyerah pada detik 20. Selalu meningkatkan diri lebih dari orang biasa. Lebihkan usaha, tekad, waktu, upaya dan lainnya daripada orang lain, maka kalian akan sukses." kata Ustad Salman.

Di samping hal itu, para santri tidak terkecuali Alif pun melakukan sahirul lail (bangun di tengah malam untuk belajar). Man thalabal ula sahiral layali, siapa yang ingin mendapatkan kemuliaan maka bekerjalah sampai malam, demikian pepatah Arab. Bentuk ikhtiar ini terdapat dalam surah al-Ra'd ayat 11, "sesungguhnya Allah tidak akan merubah sebuah kaum sehingga ia merubah dirinya sendiri".

\section{Optimis}

Salah satu ciri orang yang berhasil adalah mempunyai pendirian yang kuat dan tidak gampang menyerah."Jadi pilihlah suasana hati kalian, dalam 
keadaan yang paling kacau sekalipun. Karena kalianlah master dan penguasa hati kalian, dan hati yang selalu dikuasai pemiliknya adalah hati orang yang sukses." Kata Ustad Salman. Hipogram dari teks ini terdapat dalam surah Ali Imran ayat 102 tentang anjuran bertakwa. "Bertakwalah kepada Allah dengan sebenar-benar takwa dan jangan sekali-kali kamu mati melainkan dalam keadaan beragama Islam".

\section{Sungguh-sungguh}

Membaca al-Qur'an dianjurkan dengan menghayati maknanya dan mengerti kandungan artinya. Al-Qur'an pun diturunkan menggunakan bahasa yang indah dan mudah dimengerti. Hal ini terdapt dalam surah Qamar yang disebutkan sampai empat kali dalam ayat 17, 22, 32, dan 40. Artinya, "Dan sesungguhnya kami telah memudahkan al-Qur'an untuk pelajaran". Sedangkan haditsnya diriwayatkan oleh Abu Imamah Al Bahali, bahwa rasul bersabda:"Bacalah oleh kalian al-Qur'an karena al-Qur'an akan datang pada hari kiamat sebagai pemberi syafaat bagi yang membacanya."

\section{Rukun}

Sebagaimana dicontohkan oleh akhlak Nabi Muhammad ketika bergaul dengan saudara sesama muslim. Sesama muslim harus rukun, saling menghormati dan tidak bertengkar. Alif kecil sering berkelahi dengan temannya. Amak pun mengingatkan bahwa adab sesama muslim antara lain mengucapkan salam, tersenyum, bersaudara, tidak berkelahi, dan saling menyayangi. Surah al Hujurat ayat 10 merupakan hipogram atas teks bergaul yang baik dengan teman. Arti dari ayat ini yaitu: "sesungguhnya orang mu'min itu bersaudara, karena itu damaikanlah antara kedua saudaramu dan bertakwalah kepada Allah supaya mendapat rahmat".

\section{Qana'ah}

Alif Fikri mendapatkan nilai lima untuk mata pelajaran kesenian. Nilai tersebut diperoleh dari amaknya selaku guru kelas satu. Ayah Alif menegur istrinya, mengapa anak sendiri diberi nilai rapor lima. Ibu Alif menjawab bahwa itu sesuai dengan kemampuan Alif. Ibu Alif bersikap adil, objektif dan tidak pandang bulu. Ayah Alif mengajukan keberatan, mengapa ke- 
pada anak sendiri pelit memberi nilai, dan Alif masih kecil. Dengan tegas ibu Alif mengatakan bahwa tidak seharusnya Alif meremehkan pelajaran kesenian, dan sejak kecil ia harus diajari berusaha keras untuk mendapatkan nilai yang bagus. Rasul pernah bersabda: "Tidak ada yang lebih baik bagi seseorang yang makan sesuatu makanan, selain makanan dari hasil usahanya. Dan sesungguhnya Nabi Daud selalu makan dari hasil usahanya".

\section{Minta Ampun/Taubat}

Menjelang magrib, Alif dan teman-temannya melantunkan syair Abu Nawas di masjid Pondok Madani. Minta ampun atas semua dosa yang telah dilakukan. Hal ini terdapat dalam surah al-Tahrim ayat 8 artinya:"Bagi orang beriman untuk bertaubat kepada Allah agar Allah menutupi kesalahanmu dan memasukkan ke dalam surga". Dari Anas ra, sahabat nabi pernah mendengar bahwa Nabi Muhammad bersabda: "Bahwa manusia ketika berdoa dan minta ampun kepada Allah maka akan diampuni tidak peduli seberapa besar dosa tersebut. Meskipun dosanya sebesar awan di langit, sebesar bumi, ketika dia minta ampun maka Allah akan mengampuninya, asalkan tidak menyekutukan Allah".

\section{Berani}

Saat liburan tiba, Alif dan temannya mempunyai kesempatan menghabiskan liburan di kota Bandung. Mereka didaulat untuk mengisi ceramah pengajian di masjid Universitas Padjadjaran(UNPAD) oleh para mahasiswa. Alif, Atang dan Baso pun mengisi ceramah menggunakan bahasa Indonesia, Arab dan Inggris. Mereka bertiga berani tampil di hadapan para mahasiswa UNPAD untuk memberikan ceramah. Mereka bersedia, karena mengamalkan ajaran ballighul anni walau ayah (sampaikan sesuatu dariku walau satu ayat). Teks ini sama dengan teks dakwah, yaitu mengajak kepada kebaikan dan menjauhi kemungkaran. Ayat dakwah terdapat dalam surah Ali Imran 110, al-Nahl 125, al-Taubah 71, serta Ali Imran 104.

\section{Persatuan}

Persatuan umat Islam merupakan kekuatan yang paling tangguh untuk merebut kekuasaan. Tetapi ketika kekuasaan telah diraih maka rawan untuk disalahgunakan dan diselewengkan. Para penguasa akan terlena sehingga 
menjadi lemah. Hal ini selaras dengan pasang surut peradaban seperti yang ditulis Ibnu Khaldun dalam kitabnya al Mukoddimah. surah Ali Imran ayat 103 menggambarkan betapa pentingnya nilai persatuan dan solidaritas. "Dan berpeganglah kamu semua kepada tali Allah, dan janganlah bercerai berai". Rasul pernah bersabda bahwa orang muslim bagi muslim lainnya seperti bangunan. Sebagian menguatkan sebagian yang lainnya.

\section{Pengorbanan}

Mengabdi di jalan Allah sama dengan konsep mewakafkan diri di jalan Islam. Ustad Khalid telah menetap di Kairo selama sepuluh tahun untuk menyelesaikan pendidikan magister dan doktoralnya. Ia mendapat beasiswa atas pendidikannya tersebut. Setelah lulus, besar peluangnya ia bisa mengajar di perguruan tinggi yang bergengsi di dalam atau luar negeri. Tetapi, Ustad Khalid memilih mengabdikan ilmunya dengan kembali dan mengajar di Pondok Madani. Ia menyadari betul pengabdiannya hanya kepada Allah. Ia tidak mengharap imbalan materi, gaji ataupun rumah. Ia ikhlas melakukan ini karena Allah. Surat al-Dzariat ayat 56 merupakan hipogram dari teks pengabdian. "Dan aku (Allah) tidak menciptakan jin dan manusia melainkan untuk menyembahku (Allah)".

Sudah waktunya untuk mengamalkan ilmu yang diperoleh selama ini. Hal ini disampaikan oleh Kiai Rais ketika melepaskan para muridnya selesai menempuh ujian. Sudah tiba waktunya para murid yang telah mengamalkan ilmunya setelah empat tahun belajar di Pondok Madani."Anakku, selamat berjuang. Hidup sekali, hiduplah yang berarti, " demikian pesan Kiai Rais kepada Alif. Rasul pernah bersabda: "Orang berilmu yang rusak (karena tidak mengamalkan apa yang dia ilmui) memiliki keserupaan dengan orang yahudi. Sedangkan ahli ibadah yang rusak (karena beribadah tanpa dasar ilmu) memiliki keserupaan dengan orang nasrani."

\section{Simpulan}

Pendidikan karakter anak tidak hanya dapat dilaksanakan secara formal melalui sekolah atau madrasah. Pendidikan karakter dapat melalui media cetak dan elektronik. Pentransferan pendidikan karakter melalui media cetak dapat disimak dari cerita novel Negeri Lima Menara. Nilai 
pendidikan karakter terhadap anak banyak kita temui dalam Novel Negeri Lima Menara. Pendidikan karakter yang berasal dari olah pikir serta olah rasa antara lain: nilai keikhlasan, patuh, giat belajar, kebersamaan, jujur, gigih, tawakkal, ikhtiar, optimis, setia kawan, qana'ah, minta ampun, berani, persatuan dan pengorbanan.[]

\section{Daftar Pustaka}

Budiman, Kris, Semiotika Visual (Konsep, Isu dan Problem Ikonitas), Yogyakarta: Jalasutra, 2011.

Culler, Jonathan, Structuralist Poetics: Structuralism, Linguistic, and the Study of Literature, New York: Cornell University Press, 1982.

Djoko Pradopo, Rachmat, Kritik Sastra Indonesia Modern,Yogyakarta: Gama Media, 2002.

Lubis, AT., Penelitian Teks dan Metode Penelitian Filologi, Jakarta: Yayasan Media Alo Indonesia, 2001.

Muzayyin, Arifin, Kapita Selekta Pendidikan Islam, Jakarta: Bumi Aksara, 2003.

Rifattere, Semiotic of Poetry, London: Indiana University Press, 1978.

Soegito, AT., "Kontribusi PAI terhadap Pembentukan Karakter Bangsa", Semarang: Universitas Negeri Semarang, 2013.

Supriyadi, Asep, "Transformasi Nilai-nilai Ajaran Islam dalam Ayat-ayat Cinta Karya Habiburrahman El Shirazy: Kajian Interteks", Semarang: Program Pascasarjana UNDIP, 2006.

Santosa, Puji, Rancangan Semiotika dan Pengkajian Susastra, Bandung: Angkasa, 2004

Sutrisno dan Subiyantoro, "Kontribusi Madrasah dalam Pembentukan Karakter Bangsa", Yogyakarta: UIN Yogyakarta, 2013.

Zuchdi, Darmiyati, Pendidikan Karakter, Konsep Dasar dan Implementasi di Perguruan Tinggi, Yogyakarta: UNY Press, 2012.

Zubaidi, Desain Pendidikan Karakter Konsepsi dan Aplikasi dalam Lembaga Pendidikan, Jakarta: Kencana, 2012. 